\section{Prevention of Blindness}

ThE March issue of the Boletin de la Oficina Sanitaria Panamericana gives the following list of international societies for the prevention of blindness : The International Society for the Prophylaxis of Blindness was organized in 1929 under the presidency of the late Dr. Félix de Lapersonne, professor of ophthalmology in the Paris Medical Faculty, and held several meetings in various European capitals, the last being in Cairo in December 1937 in conjunction with the Fifteenth International Congress of Ophthalmology. Its office is at 66 Boulevard St Michel, Paris 6e. In 1930 it became united with the International Organization for the Campaign against Trachoma, the organ of which is the Revue internationule de Trachome. Uther international societies of the kind are the International Association for Blind Students, 1 Rue Etienne Dumont, Geneva, and the Spanish-American Association for the Blind, 1545 Madison Avenue, New York. Reference may also be made to the International Council of Ophthalmology, Rotterdam, and the International Federation of Ophthalmologic Societies.

\section{Bibliography of Seismology}

The Bibliography of Seismology for the period JulyDecember 1941, prepared at the Dominion Observatory, Ottawa, by Mr. Ernest A. Hodgson (now president of the Seismological Society of America), has just been received. It covers 145 items, ranging through pure and applied seismology, building construction, cosmogony, engineering, instruments, insurance, oceanography and time-keeping. About forty-five items deal with seismic prospecting and patents associated with it, and forty-two items deal with instruments, chiefly for the detection of various types of natural and artificial seismic waves. Items in NATURE are listed. Several items deal with seismic surveying in the U.S.S.R. (for example, "Prospects of Seismic Survey by the Method of Refracted Waves in the Region of Ust-Eniseisk Port" by R. M. Demenitskaia. Problemi Arktiki, No. 5, 81-92, Leningrad, 1939), and it is not known whether or not the War has interfered with many of these projects. From time to time luminous phenomena have been reported as accompanying seismic phenomena, and one such is listed: "Sur les phénomenes lumineux qui ont accompagné le tremblement de terre de Roumanie du 10 novembre 1940", G. Demetrescu and G. Petrescu, Académie Roumaine, Bulletin de la Section Scientifique, Tome 23, No. 6, pp. 5, J chart, Jan., 1941."

\section{"Thorpe's Dictionary of Applied Chemistry"}

FIvE volumes of the current edition of "Thorpe's Dictionary of Applied Chemistry" were published under the editorship of Sir Jocelyn Thorpe and Dr. Martha A. Whiteley. With the death of Sir Jocelyn Thorpe new editorial arrangements have been necessary, and in order to maintain a balance between the various branches of chemical science, an editorial board has been formed, comprising Prof. I. M. Heilbron (professor of organic chemistry and director of the Laboratories for Organic Chemistry at the Imperial College) (chairman), Prof. H. J. Emeleus (assistant professor and reader in inorggnic chemistry at the Imperial College), Prof. H. W. Melville (professor of chemistry in the University of Aberdeen), and Prof. A. R. Todd (Sir Samuel Hall professor of chemistry and director of the Chemical Laboratories in the University of Manchester). This Board will determine the general editorial policy in conjunction with the publishers. Dr. Whiteley continues as editor, and Dr. A. J. E. Welch (assistant lecturer in inorganic chemistry at the Imperial College) becomes assistant editor; thus the association with the Imperial College is being maintained. Vol. 6 of the current edition is in the press, and it is proposed to complete the edition with eight further volumes, published at yearly intervals. Although the Board does not consider that any major modification of the general character of the work is required, certain changes in the scope of the articles, particularly with regard to physical chemistry topics, are to be made.

\section{Announcements}

THE University of Marburg, with the support of the Behring Works, has founded an Emil von Behring prize consisting of a medal and a sum of five thousand gold marks. It will be awarded every two years for scientific work in medicine, veterinary medicine or natural science, with special reference to immunity and control of epidemics.

UNDER the title "Why I am a Rationalist: Books which have Influenced Me", Messrs. C. A. Watts and Co., Ltd., have published for the Rationalist Press Association, Ltd., a series of autobiographical essays. which originally appeared in the "Literary Guide". The contributors include the Right Hon. Lord Snell, Prof. J. B. S. Haldane, Marjorie Bowen, Prof. H. Levy, Ivor Brown, W. B. Curry, and others. The contributions are of varied merit but form a useful, if scarcely critical, guide to a wider range of literature than can fairly be claimed by rationalism as its own. The book may well direct readers to books which to-day do not receive the attention thoy deserve.

THe tenth annual Summer Conference on Spectroscopy and Its Applications, arranged jointly by the Optical Society of America and the Massachusetts Institute of Technology, will be held at the latter during July 20-22. A symposium on fluorescence and phosphorescence is planned in connexion with the Conference. Admittance to the Conference will be by reservation as usual. Further information and tickets can be obtained from Prof. George R. Harrison, Massachusetts Institute of Technology, Cambridge, Massachusetts. The usual courses in spectroscopy will not be given at the Massachusetts Institute of Technology this summer.

Prof. M. Polanyi and Mr. A. G. Evans write: We wish to supplement our letter entitled "Calculation of Steric Hindrance" (NATuRe, May 30, p. 608) by the following footnote which was attached to the letter in proof, but was not received in time to be printed: The presence of steric hindrance in the case of neopentyl has been briefly pointed out by Hnghes. (Trans. Far. Soc., 623; 1941) on what seem to be similar lines. He, however, interprets the slowness of reactions of the type (1) for $t$-butyl halides on a different basis. See also a recent paper by Bartlett. and Rosen (J.Amer. Chem. Soc., 64, 543 ; 1942) on steric hindrance in neopentyl halides. 